Subscriber access provided by Caltech Library

\title{
Letter
}

\section{CO Reduction to CO with $19 \%$ Efficiency in a Solar-Driven Gas Diffusion Electrode Flow Cell under Outdoor Solar Illumination}

Wen-Hui Cheng, Matthias H. Richter, Ian Sullivan, David M Larson, Chengxiang Xiang, Bruce S. Brunschwig, and Harry A Atwater

ACS Energy Lett., Just Accepted Manuscript • DOI: 10.1021/acsenergylett.9b02576 • Publication Date (Web): 09 Jan 2020

Downloaded from pubs.acs.org on January 9, 2020

\section{Just Accepted}

"Just Accepted" manuscripts have been peer-reviewed and accepted for publication. They are posted online prior to technical editing, formatting for publication and author proofing. The American Chemical Society provides "Just Accepted" as a service to the research community to expedite the dissemination of scientific material as soon as possible after acceptance. "Just Accepted" manuscripts appear in full in PDF format accompanied by an HTML abstract. "Just Accepted" manuscripts have been fully peer reviewed, but should not be considered the official version of record. They are citable by the Digital Object Identifier (DOI@). "Just Accepted" is an optional service offered to authors. Therefore, the "Just Accepted" Web site may not include all articles that will be published in the journal. After a manuscript is technically edited and formatted, it will be removed from the "Just Accepted" Web site and published as an ASAP article. Note that technical editing may introduce minor changes to the manuscript text and/or graphics which could affect content, and all legal disclaimers and ethical guidelines that apply to the journal pertain. ACS cannot be held responsible for errors or consequences arising from the use of information contained in these "Just Accepted" manuscripts. 


\title{
$\mathrm{CO}_{2}$ Reduction to $\mathrm{CO}$ with 19 \% Efficiency in a Solar-Driven Gas Diffusion Electrode Flow Cell under Outdoor Solar Illumination
}

\author{
Wen-Hui Cheng ${ }^{1}$, Matthias H. Richter², Ian Sullivan², David M. Larson³, \\ Chengxiang Xiang ${ }^{2}$, Bruce S. Brunschwig ${ }^{4 *}$, Harry A. Atwater ${ }^{1 *}$ \\ ${ }^{1}$ Department of Applied Physics and Material Science, California Institute of Technology, \\ Pasadena, CA 91125, USA. \\ 2 Division of Chemistry and Chemical Engineering, California Institute of Technology, \\ Pasadena, CA 91125, USA. \\ ${ }^{3}$ Chemical Sciences Division, Lawrence Berkeley National Laboratory, Berkeley, CA 94720 , \\ USA. \\ ${ }^{4}$ Beckman Institute, California Institute of Technology, Pasadena, CA 91125, USA. \\ *Correspondence to: $\underline{\mathrm{bsb} @ \text { caltech.edu, haa@caltech.edu }}$
}


TOC

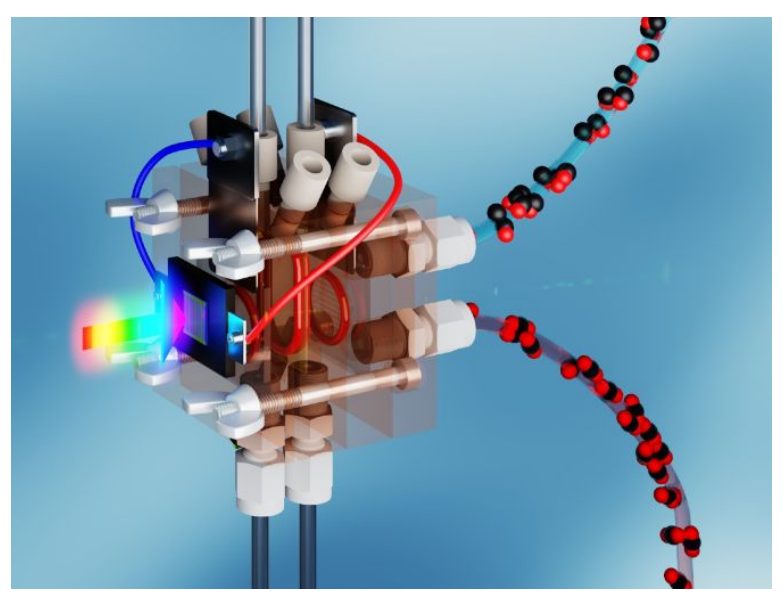

\begin{abstract}
:
Solar-driven reduction of carbon dioxide represents a carbon neutral pathway for the synthesis of fuels and chemicals. We report here results for solar-driven $\mathrm{CO}_{2}$ reduction using a gas diffusion electrode (GDE) directly powered by a photovoltaic cell. A GaInP/GaInAs/Ge triple junction photovoltaic cell was used to power a reverse-assembled gas diffusion electrode employing a Ag nanoparticle catalyst layer. The device had a solar-to-CO energy conversion efficiency of $19.1 \%$ under simulated AM 1.5G illumination at 1 Sun. The use of a reverseassembled GDE prevented transition from a wetted to a flooded catalyst bed and allowed the device to operate stably for $>150 \mathrm{~h}$ with no loss in efficiency. Outdoor measurements were performed under ambient solar illumination in Pasadena, CA, resulting in a peak solar-to-CO efficiency $18.7 \%$ with a $\mathrm{CO}$ production rate of $47 \mathrm{mg} \cdot \mathrm{cm}^{-2}$ per day and a diurnal-averaged solar to fuel conversion efficiency of $5.8 \%$.
\end{abstract}


Solar photovoltaic and wind energy conversion are rapidly growing sources of lowcarbon electric power. ${ }^{1}$ However, intermittency of the solar and wind resources over wide time scales ranging from minutes to months means solar electricity is not a dispatchable power source. Thus, efficient and inexpensive approaches for energy storage are needed for wide penetration of renewable energy into the power grid. ${ }^{2,3}$ While electrical energy storage in batteries may be important for short-term storage and grid power management, seasonal energy storage is unlikely to rely on batteries. Transformation of solar energy into chemical bonds provides a long-term energy storage strategy that opens a path for the synthesis of fuels, and chemicals. ${ }^{4}$ One approach to chemical energy storage is via solar-driven hydrogen generation, where i) photovoltaics supply carbon free electricity to the grid that is used to generate $\mathrm{H}_{2}$ by water electrolysis at high current densities; ${ }^{5}$ ii) photovoltaics are used to directly drive electrolysis at low current densities, ${ }^{6}$ or iii) an integrated photoelectrochemical device that performs unassisted direct water splitting to form $\mathrm{H}_{2} \cdot{ }^{7,8}$ Parallel to solar hydrogen generation approaches, pathways for solar-driven reduction of carbon dioxide to fuels have used i) direct electrolysis, ${ }^{9}$ ii) photovoltaic directly driven electrolysis 10 and iii) integrated photoelectrochemical conversion. ${ }^{11,12}$ Of particular interest is solar-driven reduction of carbon dioxide using a high efficiency photovoltaic (PV) device directly coupled to an electrochemical cell tailored for reduction of $\mathrm{CO}_{2}$ to $\mathrm{CO} .{ }^{13,14}$ Mixtures of solar-generated $\mathrm{CO}$ and $\mathrm{H}_{2},{ }^{15}$ could be used as syngas precursors in a future Fischer-Tropsch chemical synthesis process ${ }^{16}$ to produce high molecular weight hydrocarbon fuels, or chemicals as products. ${ }^{17}$ Carbon dioxide reduction to $\mathrm{CO}$ is generally more energy efficient and kinetically easier than direct reduction of $\mathrm{CO}_{2}$ to multicarbon products. ${ }^{14,18,19}$

Among the most efficient heterogeneous solid state catalysts for $\mathrm{CO}_{2}$ reduction to $\mathrm{CO}$ are gold, ${ }^{20,21}$ silver, ${ }^{22} \mathrm{WSe}_{2},{ }^{23}$ and $\mathrm{MoS}_{2} \cdot{ }^{24}$ The use of high surface area morphology structures such as nanoparticles can improve catalytic activity. ${ }^{25}$ Other factors that impact catalytic performance include catalyst morphology, ${ }^{20}$ cations present in the electrolyte solution, ${ }^{26}$ electrolyte concentration ${ }^{27}$ and local $\mathrm{pH} .{ }^{28}$ The state-of-the-art $\mathrm{CO}_{2}$ to $\mathrm{CO}$ conversion using a Au needle catalyst ${ }^{27}$ showed an operating current of $15 \mathrm{~mA} \cdot \mathrm{cm}^{-2}$ and $95 \%$ Faradic efficiency at $-0.35 \mathrm{~V}$ vs. RHE. However, the current record efficiency device for solar conversion of $\mathrm{CO}_{2}$ to $\mathrm{CO}$ using a solution based electrochemical cell suffered from low current density $\left(0.33 \mathrm{~mA} \cdot \mathrm{cm}^{-2}\right.$ at $-0.6 \mathrm{~V}$ vs. RHE) due to limited catalyst activity. This required the use of large area electrodes to match the 
photovoltaic device area. ${ }^{10}$ Table S1 shows overpotential and Faradic efficiency data at current densities close to $15 \mathrm{~mA} \cdot \mathrm{cm}^{-2}$ along with the electrolyte conditions and catalyst loading for various $\mathrm{Ag}$ and $\mathrm{Au}$ electrodes. The catalytic activities of the catalysts shown in Table S1 indicate that in many cases nanoparticles of Ag have a similar activity to that of Au while costing significantly less.

Bulk aqueous electrolyte cells can exhibit high catalyst overpotentials due to the limited solubility of $\mathrm{CO}_{2}(33.4 \mathrm{mM})$ in the electrolyte, a limited $\mathrm{pH}$ operating range of $\sim 6-10$, and slow ionic transport in the solution. In contrast, gas diffusion electrode (GDE) assemblies do not suffer these same restrictions. ${ }^{29-35}$ In a GDE using $1 \mathrm{~atm} \mathrm{CO}_{2}$ vapor, $\mathrm{CO}_{2}$ is transported in the vapor phase and reacts at a thin $(<100 \mathrm{~nm})$ solid-liquid-gas phase interface. In this configuration liquid state concentration and diffusion do not limit the conversion rate, resulting in lower overpotentials and higher current densities for $\mathrm{CO}_{2}$ reduction. ${ }^{30}$ Simulations have also shown that a cell using a thin $(10 \mathrm{~nm})$ layer of electrolyte on the catalysts (wetted catalyst) outperform cells with either a completely dry or a completely flooded catalyst configuration. ${ }^{36}$ These insights have led to the development of gas diffusion electrodes, ${ }^{37}$ and membrane electrode assemblies (MEA) ${ }^{38}$ with a humidified gas supply to facilitate ion conduction and water balance.

Although membrane electrode assemblies systems are more scalable, they often suffer from short-term stability due to salt precipitation or membrane dehydration at high current densities. ${ }^{39}$ Hence, we chose to work with an aqueous GDE cell configuration. In this work, we employ a triple junction photovoltaic (PV) device directly coupled with a gas diffusion electrode (GDE) as the first demonstration of an electrolyte flow type PV-GDE reactor, that provides both high selectivity and long-term stability. For a directly driven PV-GDE system, the power generated by the PV is directly supplied to the GDE. In our device, the areas of the PV photoabsorber $\left(A_{\mathrm{PV}}\right)$ and GDE $\left(A_{\mathrm{GDE}}\right)$ were both $0.31 \mathrm{~cm}^{2}$. To match the lower current density of the PV cell with the operating conditions of the anode, a relatively low catalyst loading of GDE was chosen. A Ag nanoparticle catalyst was used owing to its relatively high activity and relatively low cost, Table S1. 

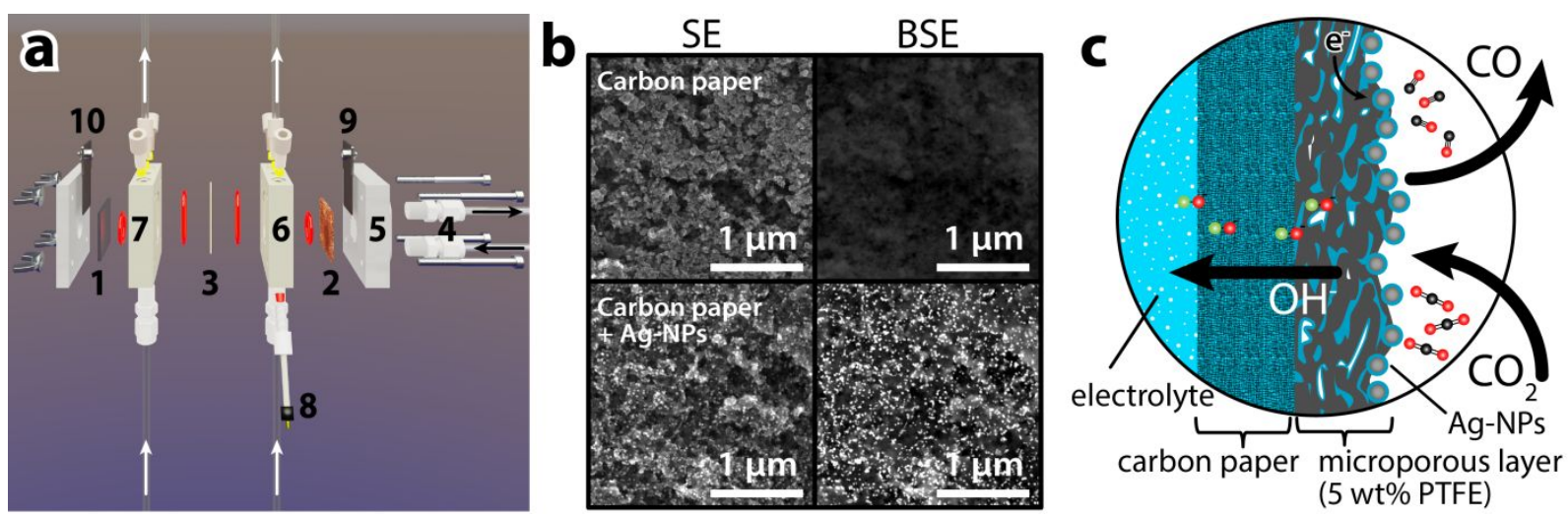

Figure 1 Gas diffusion electrode with Ag-NP catalyst. a Cell configuration composed of $1 \mathrm{NiO}_{x}$ or Pt anode, 2 Ag-NPs on Sigracet 29BC carbon paper cathode, 3 anion exchange membrane, 4 $\mathrm{CO}_{2}$ gas inlet and $\mathrm{CO} / \mathrm{CO}_{2}$ outlet, 5 Acrylic backplate, 6 catholyte chamber, 7 anolyte chamber, 8 reference electrode, 9 GDE (cathode) power connector, 10 anode power connector. Black arrows indicate the gas flow, and white arrows indicate the electrolyte flow. Note that the backplate, 5, is designed to use an interdigitated wire electrode flow field to enhance the interaction between gas and catalysts and improve $\mathrm{CO}_{2}$ utilization. (see also Figure S1) b Scanning electron microscopy images of carbon paper without (top) and with (bottom) Ag-NP catalyst, secondary electrons image (left row) backscattered electrons image (right row). c Illustration of the reverse-assembled GDE cathode cross-section with wetted catalyst and operation for $\mathrm{CO}_{2}$ reduction.

Figure 1a is an illustration of the compression flow cell employed for the evaluation of gas diffusion electrode catalytic performance. Dilute silver nanoparticles (Ag-NPs) with diameters of $\leq 50 \mathrm{~nm}$ were drop cast onto the microporous side of the GDE substrate (Sigracet 29BC). The loading of Ag-NPs in this work was measured to be $0.12 \mathrm{mg} \cdot \mathrm{cm}^{-2}$. A detailed description can be found in the Methods section. Scanning electron microscopy (SEM) images of the microporous layer with and without Ag-NPs are shown in Figure 1b. Gas was delivered to the GDE through an interdigitated electrode flow field (Figure 1a, and S1) against which the GDE is compressed to maximize the interaction of $\mathrm{CO}_{2}$ with the catalyst and gas utilization. ${ }^{40}$ Current to the GDE was supplied through the interdigitated electrode to the Ag$\mathrm{NP} /$ carbon paper substrate. Gaseous products were collected at the outlet of the flow field, which was directly connected to a gas chromatograph (for more information see Methods section). 
An issue for aqueous GDEs is flooding or saturation of the porous catalyst layer with electrolyte or water during operation. This results in a thick $(>1 \mu \mathrm{m})$ electrolyte layer and a diffusion-limited supply of $\mathrm{CO}_{2}$ to the electrode. ${ }^{41}$ To maintain the catalyst in a wetted but not flooded condition that minimizes losses of $\mathrm{CO}_{2}$ to the electrolyte and extends the operational lifetime, we assembled our aqueous GDE in a nontraditional manner with the catalyst coating of Ag-NPs facing away from the electrolyte and towards the $\mathrm{CO}_{2}$ gas supply. We denoted this configuration as a reverse-assembled GDE. The microporous layer of the GDE was treated with polytetrafluoroethylene (PTFE), which helped to prevent flooding. Needle valves in the gas and liquid output streams allowed separation of the liquid and gas phases as well as control of the pressure difference between the aqueous electrolyte and the $\mathrm{CO}_{2}$ stream. Contact angle analysis indicated that the Ag-NP coated surface was significantly less hydrophobic than the surface without Ag-NPs. Contact angle and optical microscope images of the GDE are shown in Figure $\mathrm{S} 2$.

With both the gas inlet and outlet on the same side of the GDE, the device operates in a 'flow-by' GDE configuration. The Ag-NP catalyst side of the electrode was facing the $\mathrm{CO}_{2}$ gas channel as illustrated in Figure 1c. This orientation of the Ag-NPs maintained a thin electrolyte layer on the catalyst and enhance the rate of $\mathrm{CO}_{2}$ reduction. ${ }^{36}$ The turnover frequency of the AgNP catalyst for the reverse-assembled GDE at $-0.6 \mathrm{~V}$ vs RHE was calculated as $\sim 9 \times 10^{3} \mathrm{~h}^{-1}$, see Supporting information. The anode was made from either Pt or an electrochemically activated Ni foam for three- and two-electrode measurements, respectively. An aqueous catholyte of $1 \mathrm{M}$ aqueous potassium bicarbonate $\left(\mathrm{KHCO}_{3}\right)$ or potassium hydroxide $(\mathrm{KOH})$ was used under near neutral or basic conditions, respectively. In all cases, $1 \mathrm{M} \mathrm{KOH}$ was the anolyte. The anion exchange membrane (AEM) was Selemion for neutral environment or Fumasep FAA-3-50 for alkaline environment. Electrolyte $(500 \mathrm{ml})$ was continuously pumped through the cathode chamber in a closed loop at a rate of $2 \mathrm{~mL} / \mathrm{min}$. A change of $\mathrm{pH}$ (from 14 to 13.7) was observed for the $1 \mathrm{M} \mathrm{KOH}$ catholyte after $150 \mathrm{~h}$ of continuous operation, corresponding to irreversible loss of $0.25 \mathrm{~mol} \mathrm{KOH} \mathrm{(50 \%} \mathrm{of} \mathrm{the} \mathrm{electrolyte,} \mathrm{see} \mathrm{Supporting} \mathrm{Information).} \mathrm{Further}$ improvement to reduce $\mathrm{CO}_{2}$ loss or regenerate the electrolyte would be necessary for fully sustainable operation. The neutralized carbonate electrolyte can possibly be utilized in carbonate-to-syngas system to compensate the loss of $\mathrm{CO}_{2}$ in a gas-fed MEA cell with bipolar membrane. ${ }^{42}$ 
a

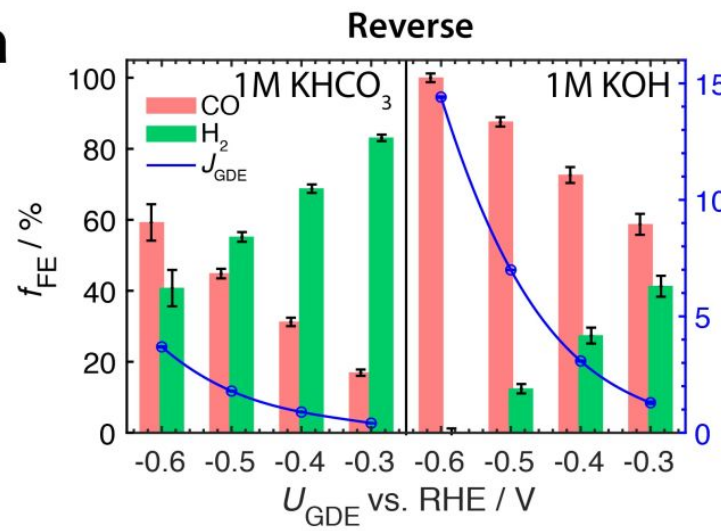

b

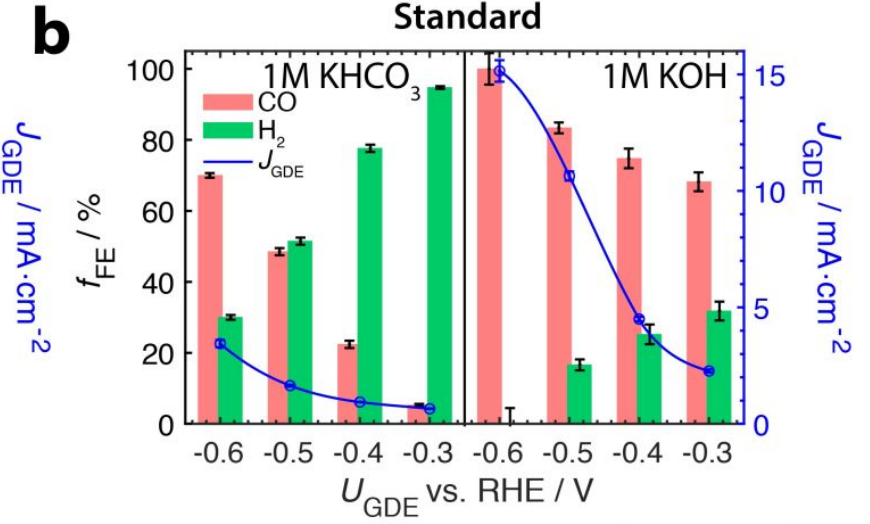

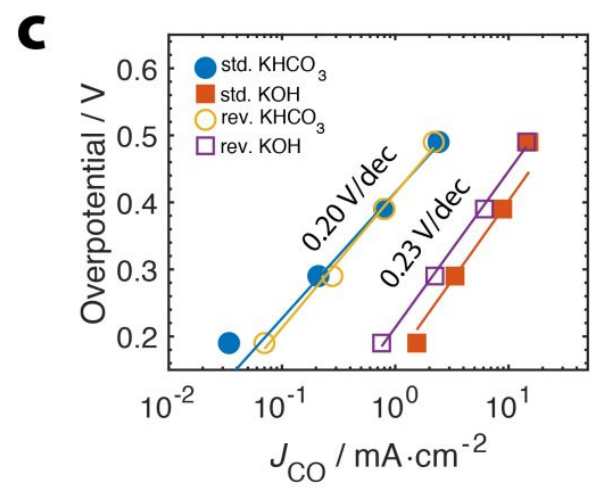
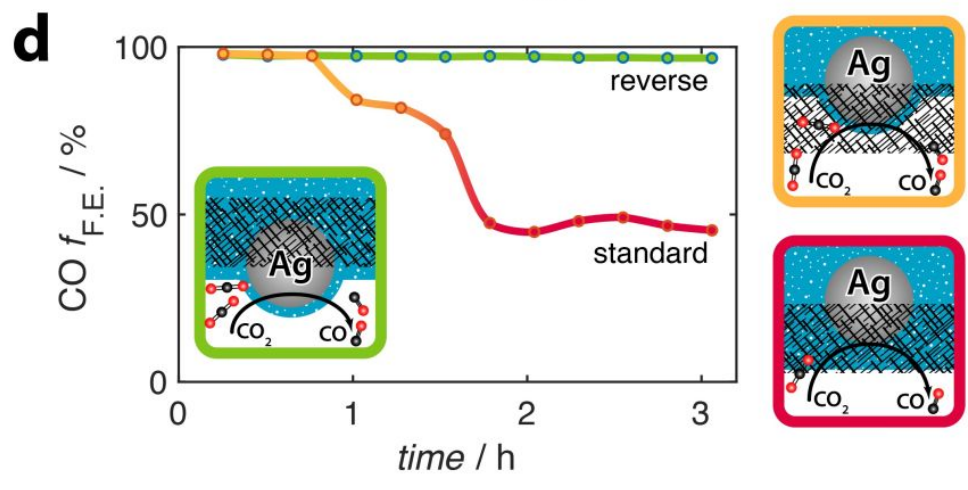

Figure 2 Dark catalysis three-electrode measurement of Ag-NPS GDE. Faradaic efficiency versus $G D E$ potential operated in $1 \mathrm{M} \mathrm{KHCO}_{3}$ (left half of graph) or $1 \mathrm{M} \mathrm{KOH}$ (right half of graph) of $\boldsymbol{a}$ the reserve-assembled $A g-N P G D E$ and $\boldsymbol{b}$ a standard-assembled Ag-NP GDE. $\boldsymbol{c}$ Overpotential versus $\mathrm{CO}$ partial current of $\mathrm{Ag}-\mathrm{NPS}$ GDE for $\mathrm{CO}_{2}$ reduction to $\mathrm{CO}$. Overpotential $=\left|U_{G D E, R H E}+0.11 V\right|, J_{C O} \equiv J_{G D E} \times f_{F E, C O}$ d Stability of reserve-assembled and standard-assembled Ag-NPs GDE operated at -0.6 V vs. RHE in $1 \mathrm{M} \mathrm{KOH}$.

Results from three-electrode measurements for reverse- and standard-assembled GDEs are shown in Figure 2a,b, respectively, for $1 \mathrm{M} \mathrm{KHCO}_{3}$ (bulk pH of 8.5) and $1 \mathrm{M} \mathrm{KOH}$ (bulk pH of 14). Current densities are substantially lower than for earlier reported GDE devices due to the low catalyst loading used to match the current from the PV (current matching). For the reverse assembled $\mathrm{GDE}$, both the Faradaic efficiency $\left(f_{\mathrm{FE}, \mathrm{CO}}\right)$ for $\mathrm{CO}$ and current density $\left(J_{\mathrm{GDE}}\right)$ increased with increasing potential with $f_{\mathrm{FE}, \mathrm{CO}}$ close to $100 \%$ at $-0.6 \mathrm{~V}$ vs. RHE in $1 \mathrm{M} \mathrm{KOH}$, Figure $2 \mathrm{a}$. Similar trends of current density and Faradaic efficiency versus applied potential were found for the standard-assembled GDE, Figure 2b. To compare the activity of the Ag-NPs in different 
orientations and $\mathrm{pH}$, overpotential analysis for $\mathrm{CO}_{2}$ reduction to $\mathrm{CO}$ was preformed, Figure 2c. The comparable Tafel slopes $(\sim 0.23 \mathrm{~V} / \mathrm{dec})$ in $\mathrm{KHCO}_{3}$ and $\mathrm{KOH}$ for either orientation indicate a similar catalytic pathway regardless of the operating conditions. The Tafel behavior plotted with potentials vs NHE falls on a rough single line (Figure S3) and suggests that the rate-determining step for the reduction on our Ag-NP GDE is not proton limited. The achievable current density and Faradaic efficiency $\left(f_{\mathrm{FE}, \mathrm{CO}}\right)$ for $\mathrm{CO}$ are higher in $1 \mathrm{M} \mathrm{KOH}$ than in $1 \mathrm{M}^{\mathrm{K} H C O}{ }_{3}$ at the same overpotential, Figure 2c, likely due to a $\mathrm{pH}$ independent rate determining step. All subsequent measurements were, therefore, performed using $1 \mathrm{M} \mathrm{KOH}$ for the PV-GDE integrated device.

Figure $2 \mathrm{~d}$ shows the Faradic efficiency for $\mathrm{CO}$ vs. time at $-0.6 \mathrm{~V}$ vs. RHE for the two GDE orientations in $\mathrm{KOH}$. For the standard configuration, the $f_{\mathrm{FE}, \mathrm{CO}}$ decreasing to $\sim 75 \%$ after $1 \mathrm{~h}$ and to $50 \%$ after $2 \mathrm{~h}$, while for the reverse configuration, the $f_{\mathrm{FE}, \mathrm{CO}}$ was $\sim 97 \%$ for $3 \mathrm{~h}$. Though similar in initial current density and $f_{\mathrm{FE}, \mathrm{CO}}$, the standard assembly, with the Ag-NP catalyst facing the electrolyte, became flooded during the first hour of operation resulting in a reduction of the Faradic efficiency.

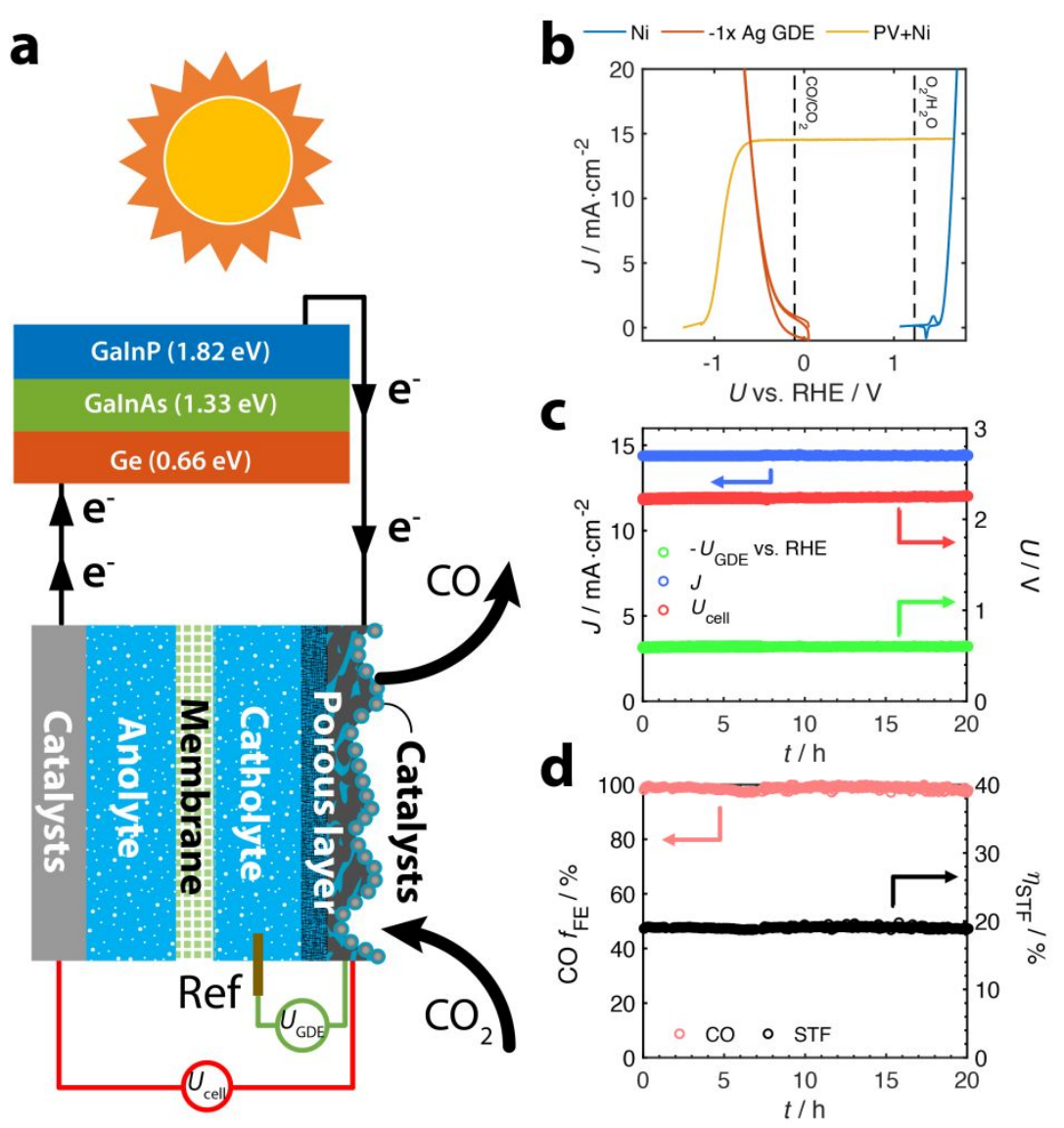


Figure 3 Light driven PV-GDE measurement $\left(A_{P V}=A_{G D E}=0.31 \mathrm{~cm}^{2}\right)$. a Illustration of wire connection between the triple junction cell and GDE cell. $\boldsymbol{b} J$-U characteristic of Ni anode, solar cell with Ni anode, and Ag-NP gas diffusion cathode under 1 Sun. c Current, GDE potential vs RHE, and cell voltage measurement over $20 \mathrm{~h}$ duration. $\boldsymbol{d}$ The corresponding CO Faradaic efficiency and solar to fuel efficiency over the same $20 \mathrm{~h}$ duration.

We performed two-electrode measurements for the GDE using an electrochemically activated nickel foam anode coupled to the GaInP/GaInAs/Ge triple junction cell. For detailed information about the solar cell see the Methods section, Figures S4-S5, and Table S2. A schematic of the cell is shown in Figure $3 \mathrm{a}$ with $1 \mathrm{M} \mathrm{KOH}$ as electrolyte using a Fumasep FAA-3-50 membrane. Both the cell potential $\left(U_{\text {cell }}\right)$ and the cathode to reference electrode potential $\left(U_{\mathrm{GDE}}\right)$ were monitored during the operation. We calculated the solar to fuel efficiency $\left(\eta_{\mathrm{STF}}\right)$ for $\mathrm{CO}_{2}$ reduction using equation 1.

$$
\eta_{S T F}=\frac{\mathrm{P}_{\text {out }}}{\mathrm{P}_{\text {in }}}=\frac{J_{\mathrm{GDE}} \cdot \Delta U_{\mathrm{rxn}} \cdot f_{\mathrm{FE}, \mathrm{CO}} \cdot A_{\mathrm{GDE}}}{P_{\mathrm{light}} \cdot A_{\mathrm{PV}}}=\frac{J \cdot \Delta U_{r x n} \cdot f_{F E, C O}}{P_{\text {light }}}
$$

Where $\Delta U_{\text {rxn }}$ is the thermodynamic potential difference between the oxygen evolution half reaction (OER) and the $\mathrm{CO}_{2}$ reduction half reaction of $1.34 \mathrm{~V}, A$ is the area of the GDE or PV with $A_{\mathrm{GDE}}=A_{\mathrm{PV}}=0.31 \mathrm{~cm}^{2}, J\left(=J_{\mathrm{GDE}}=J_{\mathrm{PV}}\right)$ is the operation current density of the system, and $P_{\text {light }}$ is the incident light irradiance $\left(\mathrm{mW} \cdot \mathrm{cm}^{-2}\right)$ on the photovoltaic. The energy efficiency for the GDE cell $\left(\eta_{\mathrm{GDE}}\right)$ was defined as follow:

$$
\eta_{\mathrm{GDE}}=\frac{\mathrm{P}_{\text {out }}}{\mathrm{P}_{\text {in }}}=\frac{\Delta U_{\mathrm{rxn}} \cdot J_{\mathrm{GDE}} \cdot A_{\mathrm{GDE}} \cdot f_{F E, C O .}}{U_{\text {cell }} \cdot J_{\mathrm{PV}} \cdot A_{\mathrm{PV}}}=\frac{\Delta U_{\mathrm{rxn}} \cdot f_{F E, C O}}{U_{\text {cell }}}
$$

where $J_{\mathrm{GDE}} \cdot A_{\mathrm{GDE}}=J_{\mathrm{PV}} \cdot A_{\mathrm{PV}}$, and $U_{\text {cell }}$ is the total operating voltage of the cell.

To evaluate the efficiency and stability, we measured cell parameters using simulated AM $1.5 \mathrm{G}$ sun illumination at 1 Sun in the laboratory, as shown in Figure $3 b-3 d$. The blue curve in Figure $3 b$ represents the performance of the electrochemically activated Ni foam anode alone, while the yellow curve indicates the behavior of PV plus anode. The red curve shows the catalytic current of the Ag-NPs GDE. The intersection between the red and yellow curves in Figure $3 \mathrm{~b}$ defines the operation point, located at $-0.6 \mathrm{~V}$ vs. RHE and $14.4 \mathrm{~mA} \cdot \mathrm{cm}^{-2}$ with a cell voltage of $2.23 \mathrm{~V}$. Figures $3 \mathrm{c}$ and $3 \mathrm{~d}$ illustrate the cell performance over 20 hours with an 
average Faradic efficiency for $\mathrm{CO}$ of $99 \pm 2 \%$ and an average $\mathrm{CO}$ production rate of $2.3 \mathrm{mg} / \mathrm{h}$. No degradation in performance was observed. From the experimental results, we calculated the average solar to $\mathrm{CO}$ efficiency for the $20 \mathrm{~h}$ operation as $19.1 \pm 0.2 \%$, with an average energy efficiency $\eta_{\mathrm{GDE}}$ of $59.4 \pm 0.6 \%$. The error bars were obtained as the variation within the $20 \mathrm{~h}$ of operation. All the experimental results are summarized in Table S3. The chemical composition of the Ag-NP catalyst layer was examined before and after the reaction by X-ray photoelectron spectroscopy as shown in Figure S6. No obvious changes were observed other than the absorption of potassium after operation with the Ag-NPs catalyst maintained its metallic phase.

The solar to $\mathrm{CO}$ efficiency of $19.1 \%$ represents a new record efficiency. A performance comparison with the current state-of-the-art PV-electrolyzer for $\mathrm{CO}_{2}$ reduction to $\mathrm{CO}$ is shown in Table S4. The PV-GDE device had a CO production rate per projected cathode area 50 times higher than for the bulk electrolyte device $\left(7.4 \mathrm{mg} \cdot \mathrm{h}^{-1} \cdot \mathrm{cm}^{-2}\right.$ versus $\left.0.145 \mathrm{mg} \cdot \mathrm{h}^{-1} \cdot \mathrm{cm}^{-2}\right)$ with greatly improved stability (20 h with no degradation versus $15 \%$ loss in $5 \mathrm{~h}$ ). ${ }^{10} \mathrm{~A}$ similar PVGDE device operated under 3.25 Suns illumination with $A_{\mathrm{GDE}}=1 \mathrm{~cm}^{2}, A_{\mathrm{PV}}=0.31 \mathrm{~cm}^{2},(3.25 \approx$ $\left.A_{\mathrm{GDE}} / A_{\mathrm{PV}}\right)$ showed over 150 hours of stability, with an average Faradic efficiency of $96 \pm 2 \%$, an average solar to $\mathrm{CO}$ efficiency of $18.9 \pm 0.5 \%$, and an average energy efficiency $\eta_{\mathrm{GDE}}$ of $53.7 \pm 1.2 \%$, Figure S7. 
Figure 4 Outdoor assessments of solar driven PV-GDE in Pasadena, CA $\left(A_{P V}=A_{G D E}=0.31 \mathrm{~cm}^{2}\right)$. The solar irradiance was monitored with a calibrated silicon photodiode. Operation current density $J\left(=J_{G D E}=J_{P V}\right)$, cell voltage $U_{\text {cell, }} G D E$ potential $U_{G D E}$ vs. RHE, CO Faradaic efficiency $f_{\mathrm{FE}, \mathrm{CO}}$ and solar to fuel efficiency $\eta_{S T F}$ were recorded for a $24 \mathrm{~h}$ day cycle.

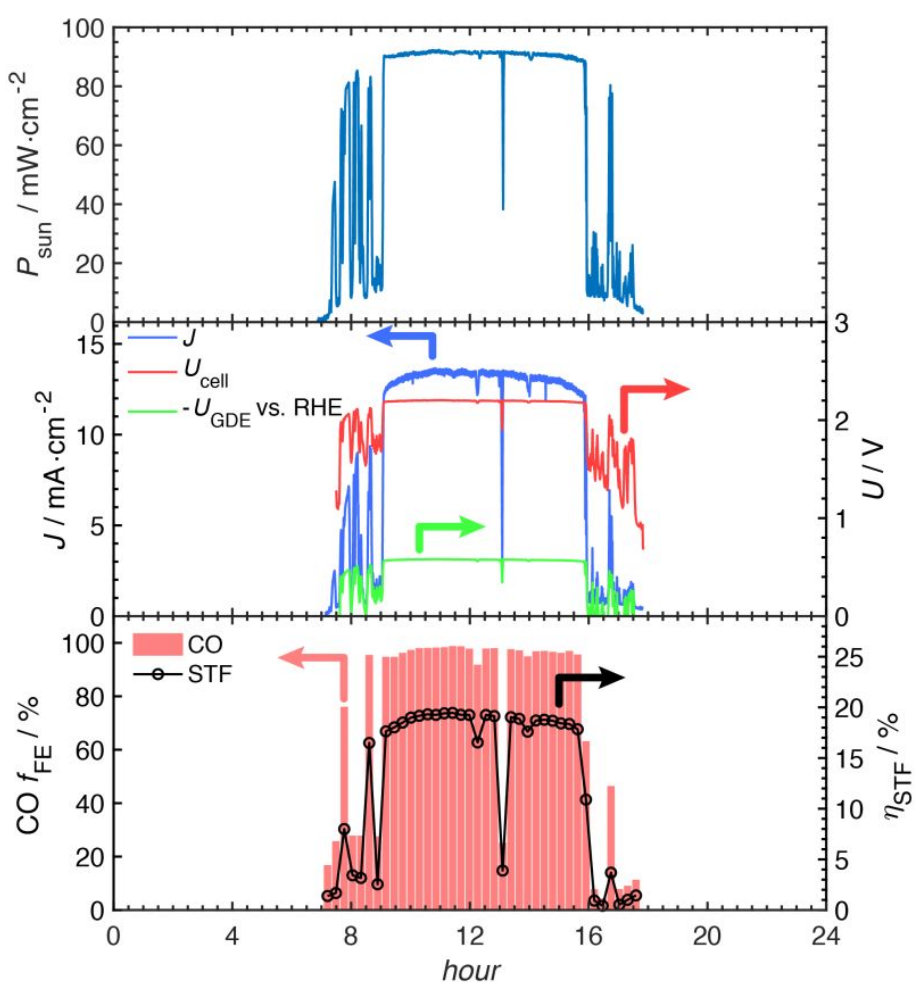

Full day outdoor tests were conducted with online gas product analysis in order to obtain the solar to fuel efficiency over the entire day. Results are shown in Figure 4. The triple junction cell and a calibrated silicon photodiode were mounted on a solar tracker to maintain optimum orientation toward the Sun (see illustration in Figure S8). The dips in sun intensity at 7:00am - 9:00am and 4:00 - 6:00 p.m. in the data were the result of trees blocking the sunlight. The system operated at a cell voltage of $2.20 \mathrm{~V}$ and GDE potential of $-0.57 \mathrm{~V}$ vs. RHE under natural full sun illumination. A Faradaic efficiency of $96 \pm 8 \%$ and solar to fuel conversion efficiency of $18.7 \pm 1.7 \%$ was observed over an optimal $6 \mathrm{~h}$ period within the day. The diurnalaveraged solar to fuel conversion efficiency was $5.8 \%$. The CO production rate for one day under actual outdoor sun conditions was calculated to be $15 \mathrm{mg}$ /day of CO. Another outdoor 
demonstration used a lens to concentrate the sunlight producing an irradiance of 3.25 Suns $(C=$ $3.25, A_{\mathrm{GDE}}=1 \mathrm{~cm}^{2}, A_{\mathrm{PV}}=0.31 \mathrm{~cm}^{2}$ ) with data included in Figure $\mathrm{S} 9$ and Table $\mathrm{S} 3$ with a $\mathrm{CO}$ generation rate of $50 \mathrm{mg} /$ day. Using this calculated rate, a system scale up to $1 \mathrm{~m}^{2}$ would result in a $\mathrm{CO}$ production rate of $0.5 \mathrm{~kg} /$ day.

The performance of our directly coupled PV-GDE device was compared to a DC-DC converter coupled PV and GDE with power-matching electronics. We simulate DC-DC converter output curves with the input of our solid-state PV curve as shown in Figure S10. Though the DC-DC converter can track the maximum power point (MPP) of the PV, a practical loss of $5-10 \%$ is expected. ${ }^{43}$ The operating point for the directly driven PV-GDE cell is $U_{\text {cell }}=2.23 \mathrm{~V}, J=14.4 \mathrm{~mA} \cdot \mathrm{cm}^{-2}$ with a maximum efficiency of $19.3 \%$. With a $95 \%$ efficient DC-DC converter, the operation point would be $U_{\text {cell }}=2.22 \mathrm{~V}, J=13.8 \mathrm{~mA} \cdot \mathrm{cm}^{-2}$ with a maximum efficiency of $18.5 \%$. For a $90 \%$ efficient DC-DC converter, the operation point would be $U_{\text {cell }}=2.20 \mathrm{~V}, J=13.2 \mathrm{~mA} \cdot \mathrm{cm}^{-2}$ with a maximum efficiency of $17.7 \%$. The maximum efficiencies are calculated assuming $100 \%$ CO Faradic efficiency. All systems are summarized in Table S3. The slightly higher efficiency of our directly driven PV-GDE device, compared to the same setup with integrated DC-DC converter and power matching electronics, reveals the potential of developing a directly coupled PV-GDE device with its reduced complexity.

In summary, we have demonstrated a highly efficient solar-driven $\mathrm{CO}_{2}$ reduction device for $\mathrm{CO}$ generation using a flow-by reverse-assembled gas diffusion electrode cell directly coupled to a triple junction solar cell. The reverse-assembled GDE is designed to minimize parasitic $\mathrm{CO}_{2}$ losses, utilizing a high $\mathrm{CO}_{2}$ concentration and low overpotential catalysts for the $\mathrm{CO}_{2}$ reduction reaction. The Ag-NPs based catalyst exhibited near unity Faradic efficiency towards $\mathrm{CO}$ generation at approximately $-0.6 \mathrm{~V}$ vs. RHE in $1 \mathrm{M} \mathrm{KOH}$ electrolyte. The PV-GDE system was evaluated under both laboratory AM 1.5G simulated solar irradiation and outdoor real sun conditions. Near-unity Faradic efficiency was observed for $\mathrm{CO}_{2}$-to-CO conversion and an average solar-to-CO energy efficiency of $19.1 \%$ was achieved with AM 1.5G illumination at 1 Sun, leading to over 50 times higher CO production rate per catalyst area than the current record photovoltaic-driven electrolysis device. The GDE was demonstrated to be stable for over 150 hours without degradation, supporting our hypothesis that, by using a reverse-assembled GDE device configuration with the catalyst layer facing towards the $\mathrm{CO}_{2}$ gas supply, we could 
extend the system operation time without suffering a transition from a wetted to a flooded gas diffusion layer. Under outdoor sun conditions, the PV-GDE system exhibited a solar to CO conversion efficiency of $18.7 \%$ during noontime, and yielded a $\mathrm{CO}$ production rate of $15 \mathrm{mg} \cdot \mathrm{cm}^{-2}$ per day. This reverse-assembled PV-GDE establishes a new efficiency record for directly solar-driven $\mathrm{CO}_{2}$ reduction, and offers an example of a very high efficiency, stable device for solar $\mathrm{CO}_{2}$ conversion. 


\begin{abstract}
ASSOCIATED CONTENT
Supporting Information

The Supporting Information is available free of charge on the ACS Publications website. Methods, calculations of solar to fuel efficiency, GDE efficiency, turn over frequency, cell potentials, $\mathrm{CO}_{2}$ loss, supporting figures and tables.
\end{abstract}

\author{
AUTHOR INFORMATION \\ Corresponding Authors \\ *E-mail: bsb@caltech.edu \\ *E-mail: $\underline{\text { haa@caltech.edu }}$ \\ ORCID \\ Wen-Hui Cheng: 0000-0003-3233-4606 \\ Matthias H. Richter: 0000-0003-0091-2045 \\ Ian Sullivan: 0000-0003-0632-4607 \\ Bruce S. Brunschwig: 0000-0002-6135-6727 \\ Harry A. Atwater: 0000-0001-9435-0201
}

\title{
Author Contributions
}

W.H.C., M.H.R., and H.A.A. conceived of the experimental study. W.H.C. and M.H.R. executed the experiments and did the data analysis. D.M.L., I.S., B.S.B., and C.X. provided technical support and scientific discussion. W.H.C., M.H.R., B.S.B., and H.A.A. wrote the paper and all authors commented on the manuscript.

\section{Notes}

The authors declare no competing financial interest.

\section{ACKNOWLEDGMENTS}

This work was supported through the Office of Science of the U.S. Department of Energy (DOE) under award no. DE SC0004993 to the Joint Center for Artificial Photosynthesis, a DOE Energy Innovation Hub. Research was in part carried out at the Molecular Materials Research Center of the Beckman Institute of the California Institute of Technology. 


\section{References}

(1) Davis, S. J.; Lewis, N. S.; Shaner, M. R.; Aggarwal, S.; Arent, D.; Azevedo, I. L.; Benson, S. M.; Bradley, T.; Brouwer, J.; Chiang, Y.-M.; Clack, C. T. M.; Cohen, A.; Doig, S.; Edmonds, J.; Fennell, P.; Field, C. B.; Hannegan, B.; Hodge, B.-M.; Hoffert, M. I.; Ingersoll, E.; Jaramillo, P.; Lackner, K. S.; Mach, K. J.; Mastrandrea, M.; Ogden, J.; Peterson, P. F.; Sanchez, D. L.; Sperling, D.; Stagner, J.; Trancik, J. E.; Yang, C.-J.; Caldeira, K. Net-Zero Emissions Energy Systems. Science 2018, 360 (6396), eaas9793. Armstrong, R. C.; Wolfram, C.; de Jong, K. P.; Gross, R.; Lewis, N. S.; Boardman, B.; Ragauskas, A. J.; Ehrhardt-Martinez, K.; Crabtree, G.; Ramana, M. V. The Frontiers of Energy. Nature Energy 2016, 1 (1), 15020.

(3) Shaner, M. R.; Davis, S. J.; Lewis, N. S.; Caldeira, K. Geophysical Constraints on the Reliability of Solar and Wind Power in the United States. Energ. Environ. Sci. 2018, 11 (4), 914-925.

(4) Lewis, N. S. Toward Cost-Effective Solar Energy Use. Science 2007, 315 (5813), 798801.

(5) Gray, E. M.; Webb, C. J.; Andrews, J.; Shabani, B.; Tsai, P. J.; Chan, S. L. I. Hydrogen Storage for Off-Grid Power Supply. Int J Hydrogen Energ 2011, 36 (1), 654-663.

(6) Jia, J.; Seitz, L. C.; Benck, J. D.; Huo, Y.; Chen, Y.; Ng, J. W. D.; Bilir, T.; Harris, J. S.; Jaramillo, T. F. Solar Water Splitting by Photovoltaic-Electrolysis with a Solar-toHydrogen Efficiency Over 30\%. Nat. Commun. 2016, 7, 13237.

(7) Young, J. L.; Steiner, M. A.; Döscher, H.; France, R. M.; Turner, J. A.; Deutsch, T. G. Direct Solar-to-Hydrogen Conversion via Inverted Metamorphic Multi-Junction Semiconductor Architectures. Nature Energy 2017, 2, 17028.

(8) Cheng, W.-H.; Richter, M. H.; May, M. M.; Ohlmann, J.; Lackner, D.; Dimroth, F.; Hannappel, T.; Atwater, H. A.; Lewerenz, H. J. Monolithic Photoelectrochemical Device for Direct Water Splitting with 19\% Efficiency. ACS Energy Lett. 2018, 3 (8), 17951800 .

(9) Seh, Z. W.; Kibsgaard, J.; Dickens, C. F.; Chorkendorff, I.; Nørskov, J. K.; Jaramillo, T. F. Combining Theory and Experiment in Electrocatalysis: Insights Into Materials Design. Science 2017, 355 (6321), eaad4998.

(10) Schreier, M.; Héroguel, F.; Steier, L.; Ahmad, S.; Luterbacher, J. S.; Mayer, M. T.; Luo, J.; Grätzel, M. Solar Conversion of $\mathrm{CO}_{2}$ To CO Using Earth-Abundant Electrocatalysts Prepared by Atomic Layer Modification of CuO. Nature Energy 2017, 2 (7), 17087. (11) Gurudayal; Beeman, J. W.; Bullock, J.; Wang, H.; Eichhorn, J.; Towle, C.; Javey, A.; Toma, F. M.; Mathews, N.; Ager, J. W., III. Si Photocathode with Ag-Supported Dendritic Cu Catalyst for $\mathrm{CO}_{2}$ Reduction. Energ. Environ. Sci. 2019, 12 (3), 1068-1077. Zhou, X.; Liu, R.; Sun, K.; Chen, Y.; Verlage, E.; Francis, S. A.; Lewis, N. S.; Xiang, C. Solar-Driven Reduction of 1 atm of $\mathrm{CO}_{2}$ To Formate at 10\% Energy-Conversion Efficiency by Use of a $\mathrm{TiO}_{2}$-Protected III-V Tandem Photoanode in Conjunction with a Bipolar Membrane and a Pd/C Cathode. ACS Energy Lett. 2016, 1 (4), 764-770. Romero Cuellar, N. S.; Wiesner-Fleischer, K.; Fleischer, M.; Rucki, A.; Hinrichsen, O. Advantages of $\mathrm{CO}$ Over $\mathrm{CO}_{2}$ As Reactant for Electrochemical Reduction to Ethylene, Ethanol and N-Propanol on Gas Diffusion Electrodes at High Current Densities. Electrochim. Acta 2019, 307, 164-175. 
(14) Zhou, X.; Xiang, C. Comparative Analysis of Solar-to-Fuel Conversion Efficiency: a Direct, One-Step Electrochemical $\mathrm{CO}_{2}$ Reduction Reactor Versus a Two-Step, Cascade Electrochemical $\mathrm{CO}_{2}$ Reduction Reactor. ACS Energy Lett. 2018, 3 (8), 1892-1897.

$$
\text { Delacourt, C.; Ridgway, P. L.; Kerr, J. B.; Newman, J. Design of an Electrochemical }
$$
Cell Making Syngas $\left(\mathrm{CO}+\mathrm{H}_{2}\right)$ From $\mathrm{CO}_{2}$ And $\mathrm{H}_{2} \mathrm{O}$ Reduction at Room Temperature. $J$. Electrochem. Soc. 2008, 155 (1), B42-B49.

Schulz, H. Short History and Present Trends of Fischer-Tropsch Synthesis. Appl Catal A-Gen 1999, 186 (1-2), 3-12.

Nielsen, D. U.; Hu, X.-M.; Daasbjerg, K.; Skrydstrup, T. Chemically and Electrochemically Catalysed Conversion of $\mathrm{CO}_{2}$ To $\mathrm{CO}$ with Follow-Up Utilization to Value-Added Chemicals. Nature Catalysis 2018, 1 (4), 244-254.

Lum, Y.; Ager, J. W., III. Sequential Catalysis Controls Selectivity in Electrochemical $\mathrm{CO}_{2}$ Reduction on Cu. Energy Environ. Sci. 2018, 11 (10), 2935-2944.

Jouny, M.; Luc, W.; Jiao, F. High-Rate Electroreduction of Carbon Monoxide to MultiCarbon Products. Nature Catalysis 2018, 1 (10), 748-755.

Welch, A. J.; DuChene, J. S.; Tagliabue, G.; Davoyan, A.; Cheng, W.-H.; Atwater, H. A. Nanoporous Gold as a Highly Selective and Active Carbon Dioxide Reduction Catalyst. ACS Appl. Energy Mater. 2018, 2 (1), 164-170.

Chen, Y.; Li, C. W.; Kanan, M. W. Aqueous $\mathrm{CO}_{2}$ Reduction at Very Low Overpotential on Oxide-Derived Au Nanoparticles. J. Am. Chem. Soc. 2012, 134 (49), 19969-19972. Hatsukade, T.; Kuhl, K. P.; Cave, E. R.; Abram, D. N.; Jaramillo, T. F. Insights Into the Electrocatalytic Reduction of $\mathrm{CO}_{2}$ On Metallic Silver Surfaces. Phys. Chem. Chem. Phys. 2014, 16 (27), 13814-13819.

Asadi, M.; Kim, K.; Liu, C.; Addepalli, A. V.; Abbasi, P.; Yasaei, P.; Phillips, P.; Behranginia, A.; Cerrato, J. M.; Haasch, R.; Zapol, P.; Kumar, B.; Klie, R. F.; Abiade, J.; Curtiss, L. A.; Salehi-Khojin, A. Nanostructured Transition Metal Dichalcogenide Electrocatalysts for $\mathrm{CO}_{2}$ Reduction in Ionic Liquid. Science 2016, 353 (6298), 467-470. Asadi, M.; Kumar, B.; Behranginia, A.; Rosen, B. A.; Baskin, A.; Repnin, N.; Pisasale, D.; Phillips, P.; Zhu, W.; Haasch, R.; Klie, R. F.; Král, P.; Abiade, J.; Salehi-Khojin, A. Robust Carbon Dioxide Reduction on Molybdenum Disulphide Edges. Nat. Commun. 2014, 5, ncomms5470.

Cheng, T.; Huang, Y.; Xiao, H.; Goddard, W. A., III. Predicted Structures of the Active Sites Responsible for the Improved Reduction of Carbon Dioxide by Gold Nanoparticles. 2017, 8 (14), 3317-3320.

Singh, M. R.; Kwon, Y.; Lum, Y.; Ager, J. W., III; Bell, A. T. Hydrolysis of Electrolyte Cations Enhances the Electrochemical Reduction of $\mathrm{CO}_{2}$ Over $\mathrm{Ag}$ and Cu. J. Am. Chem. Soc. 2016, 138 (39), 13006-13012.

Liu, M.; Pang, Y.; Zhang, B.; De Luna, P.; Voznyy, O.; Xu, J.; Zheng, X.; Dinh, C. T.; Fan, F.; Cao, C.; de Arquer, F. P. G.; Safaei, T. S.; Mepham, A.; Klinkova, A.; Kumacheva, E.; Filleter, T.; Sinton, D.; Kelley, S. O.; Sargent, E. H. Enhanced Electrocatalytic $\mathrm{CO}_{2}$ Reduction via Field-Induced Reagent Concentration. Nature 2016, 537 (7620), 382-386.

Varela, A. S.; Kroschel, M.; Reier, T.; Strasser, P. Controlling the Selectivity of $\mathrm{CO}_{2}$ Electroreduction on Copper: the Effect of the Electrolyte Concentration and the Importance of the Local pH. Catal. Today 2016, 260, 8-13. 
Verma, S.; Lu, X.; Ma, S.; Masel, R. I.; Kenis, P. J. A. The Effect of Electrolyte Composition on the Electroreduction of $\mathrm{CO}_{2}$ To $\mathrm{CO}$ on Ag Based Gas Diffusion Electrodes. Phys. Chem. Chem. Phys. 2016, 18 (10), 7075-7084.

Higgins, D.; Hahn, C.; Xiang, C.; Jaramillo, T. F.; Weber, A. Z. Gas-Diffusion Electrodes for Carbon Dioxide Reduction: a New Paradigm. ACS Energy Lett. 2019, 4 (1), 317-324.

Singh, M. R.; Papadantonakis, K.; Xiang, C.; Lewis, N. S. An Electrochemical Engineering Assessment of the Operational Conditions and Constraints for Solar-Driven Water-Splitting Systems at Near-Neutral pH. Energ. Environ. Sci. 2015, 8 (9), 27602767.

(32) Lobaccaro, P.; Singh, M. R.; Clark, E. L.; Kwon, Y.; Bell, A. T.; Ager, J. W., III. Effects of Temperature and Gas-Liquid Mass Transfer on the Operation of Small Electrochemical Cells for the Quantitative Evaluation of $\mathrm{CO}_{2}$ Reduction Electrocatalysts. Phys. Chem. Chem. Phys. 2016, 18 (38), 26777-26785.

Weng, L.-C.; Bell, A. T.; Weber, A. Z. Towards Membrane-Electrode Assembly Systems for $\mathrm{CO}_{2}$ Reduction: a Modeling Study. Energ. Environ. Sci. 2019, 12 (6), 19501968.

(34) Song, J. T.; Song, H.; Kim, B.; Oh, J. Towards Higher Rate Electrochemical $\mathrm{CO}_{2}$ Conversion: From Liquid-Phase to Gas-Phase Systems. Catalysts 2019, 9 (3), 224. Li, J.; Chen, G.; Zhu, Y.; Liang, Z.; Pei, A.; Wu, C.-L.; Wang, H.; Lee, H. R.; Liu, K.; $\mathrm{Chu}, \mathrm{S}$.; Cui, Y. Efficient Electrocatalytic $\mathrm{CO}_{2}$ Reduction on a Three-Phase Interface. Nature Catalysis 2018, 1 (8), 592-600.

Weng, L.-C.; Bell, A. T.; Weber, A. Z. Modeling Gas-Diffusion Electrodes for $\mathrm{CO}_{2}$ Reduction. Phys. Chem. Chem. Phys. 2018, 20, 16973-16984.

Cook, R. L.; MacDuff, R. C.; Sammells, A. F. High Rate Gas Phase $\mathrm{CO}_{2}$ Reduction to Ethylene and Methane Using Gas Diffusion Electrodes. J. Electrochem. Soc. 1990, 137 (2), 607-608.

Hori, Y.; Ito, H.; Okano, K.; Nagasu, K.; Sato, S. Silver-Coated Ion Exchange Membrane Electrode Applied to Electrochemical Reduction of Carbon Dioxide. Electrochim. Acta 2003, 48 (18), 2651-2657. CRC Handbook of Chemistry and Physics; Lide, D. R., Ed.; New York, 2003. Ripatti, D. S.; Veltman, T. R.; Kanan, M. W. Carbon Monoxide Gas Diffusion Electrolysis That Produces Concentrated $\mathrm{C}_{2}$ Products with High Single-Pass Conversion. Joule 2019, 3 (1), 240-256.

Dinh, C. T.; Burdyny, T.; Kibria, M. G.; Seifitokaldani, A.; Gabardo, C. M.; de Arquer, F. P. G.; Kiani, A.; Edwards, J. P.; De Luna, P.; Bushuyev, O. S.; Zou, C.; QuinteroBermudez, R.; Pang, Y.; Sinton, D.; Sargent, E. H. $\mathrm{CO}_{2}$ Electroreduction to Ethylene via Hydroxide-Mediated Copper Catalysis at an Abrupt Interface. Science 2018, 360 (6390), 783-787.

Li, Y. C.; Lee, G.; Yuan, T.; Wang, Y.; Nam, D.-H.; Wang, Z.; Garcia de Arquer, F. P.; Lum, Y.; Dinh, C. T.; Voznyy, O.; Sargent, E. H. $\mathrm{Co}_{2}$ Electroreduction From Carbonate Electrolyte. ACS Energy Lett. 2019, 4 (6), 1427-1431.

Hossain, M. Z.; Rahim, N. A.; Selvaraj, J. A. L. Recent Progress and Development on Power DC-DC Converter Topology, Control, Design and Applications: a Review. Renewable and Sustainable Energy Reviews 2018, 81, 205-230. 